\title{
Screening for amylolytic activity and characterization of thermophilic Actinobacteria isolated from a geothermal area in West Java, Indonesia
}

\author{
WINDA AYU SYAFITRI ${ }^{1, *}$, FITRIA NINGSIH ${ }^{1,2, *}$, PUTRI PRATIWI SETYANINGSIH ${ }^{1}$, \\ MAZYTHA KINANTI RACHMANIA ${ }^{1}$, DHIAN CHITRA AYU FITRIA SARI ${ }^{1,2}$, SHUHEI YABE ${ }^{3,4}$, \\ AKIRA YOKOTA ${ }^{3}$, ARIYANTI OETARI ${ }^{1,2}$, WELLYZAR SJAMSURIDZAL ${ }^{1,2, \boldsymbol{r}}$ \\ ${ }^{1}$ Department of Biology, Faculty of Mathematics and Natural Sciences, Universitas Indonesia, Kampus UI Depok, Depok 16424, Indonesia. \\ ${ }^{2}$ Center of Excellence for Indigenous Biological Resources-Genome Studies, Faculty of Mathematics and Natural Sciences, Universitas Indonesia, \\ Kampus UI Depok, Depok 16424, Indonesia. "email: sjwelly@hotmail.com; sjwelly@ sci.ui.ac.id. \\ ${ }^{3}$ Department of Microbial Resources, Graduate School of Agricultural Science, Faculty of Agriculture, Tohoku University, 468-1 Aoba, Aramaki, Aoba- \\ ku, Sendai, Miyagi 980-0845, Japan. \\ ${ }^{4}$ Hazaka Plant Research Center, Kennan Eisei Kogyo Co., Ltd., 44 Aza-Inariyama, Oaza-Ashitate, Murata-cho, Shibata-gun, Miyagi 989-1311, Japan.
}

Manuscript received: 11 June 2019. Revision accepted: 24 June 2019.

\begin{abstract}
Syafitri WA, Ningsih F, Setyaningsih PP, Rachmania MK, Sari DCAF, Yabe S, Yokota A, Oetari A, Sjamsuridzal W. 2019. Screening for amylolytic activity and characterization of thermophilic Actinobacteria isolated from a geothermal area in West Java, Indonesia. Biodiversitas 20: 1929-1938. In this study, we describe the screening for amylolytic activity of 17 thermophilic Actinobacteria isolates obtained from the soil of Cisolok geysers, a geothermal area in West Java, Indonesia. All isolates were screened for amylolytic activity by the starch-agar plate method at various temperatures. The results showed that all of isolates were able to grow at $45^{\circ} \mathrm{C}$. The growth abilities of the isolates grown in ISP 1 medium varied at temperatures from 45 to $60^{\circ} \mathrm{C}$. Fifteen of the 17 isolates showed amylolytic activity at $45^{\circ} \mathrm{C}, 13$ showed such activity at $50^{\circ} \mathrm{C}$, and four showed activity at $55^{\circ} \mathrm{C}$. Only three isolates, designated SL1-2-R-2, SL1-2-R-3, and SL1-2-R-4, showed growth and amylolytic activity at $60^{\circ} \mathrm{C}$. These three isolates were selected for molecular identification. The nearly full-length of $16 \mathrm{~S}$ rRNA gene sequences data showed that these three isolates have a similarity of $99.93-100 \%$ with Actinomadura keratinilytica WCC-2265 ${ }^{\mathrm{T}}$ and of $98.74-98.91 \%$ with A. miaoliensis BC 44T-5 ${ }^{\mathrm{T}}$. Phylogenetic tree shows that all three isolates are clustered together in a monophyletic group with the type strain of A. keratinilytica WCC-2265 ${ }^{\mathrm{T}}$ as their most closely related species, with $100 \%$ bootstrap support. Based on sequencing of the $16 \mathrm{~S}$ rRNA gene, phylogenetic comparison, and phenotypic characterization, the three isolates were identified as A. keratinilytica.
\end{abstract}

Keywords: Amylolytic activity, geothermal area, soil, thermophilic Actinobacteria

\section{INTRODUCTION}

Actinobacteria are Gram-positive filamentous bacteria, which grow by a combination of tip extension and branching of the hyphae. Most Actinobacteria are saprophytic and soil-dwelling organisms, thus they are abundant in soil (Barka et al. 2016). Actinobacteria occur in various environments, including extreme environments defined by high temperatures, such as geothermal and volcanic areas, terrestrial hot springs, and geysers (Mehta and Satyanarayana 2013; Shivlata and Satyanarayana 2015). Thermophilic Actinobacteria can grow at relatively high temperatures ranging from 40 to $80^{\circ} \mathrm{C}$ (Shivlata and Satyanarayana 2015). In order to survive under these extreme environmental conditions, thermophilic Actinobacteria use adaptive strategies such as production of specific enzymes (Shivlata and Satyanarayana 2015).

Actinobacteria are also known to play an important role as producers of several enzymes (Liu et al. 2016), and are able to use a wide variety of nutritional sources, including various complex polysaccharides. Various enzymes of industrial use have been derived from various genera of

*These authors contributed equally to the work
Actinobacteria (Salwan and Sharma 2018).

Starch is a plant polysaccharide of considerable significance for humans that can be processed enzymatically into a variety of different products (Wang and Copeland 2013). Starch is a biopolymer composed of two polymers, amylose and amylopectin. Amylose is an essentially linear molecule in which the glucose units are linked through $\alpha-1,4$ bonds. Amylopectin is a highly branched structure with $\alpha-1,6$ bonds at the branch point (Sundarram et al. 2014). The starch industry demands large amount of amylolytic enzymes for hydrolysis and modification, which requires a combination of enzymes, including $\alpha$-amylases, glucoamylases or $\beta$-amylases and isoamylases or pullulanases (Kikani et al. 2010).

Amylases degrade starch by the hydrolysis of $\alpha-1,4$ and $\alpha$-1,6-glycosidic linkages to smaller carbohydrates consisting of glucose units (Sundarram et al. 2014). Amylases play an important role in the food, fermentation, textile, and paper industries (Gopinanth et al. 2017). Starch conversion requires $\alpha$-amylases to be active at high temperatures during gelatinization $\left(100-110^{\circ} \mathrm{C}\right)$ and liquefaction $\left(80-90^{\circ} \mathrm{C}\right)$ for low-cost processes (Kikani et al. 2010). A previous study reported that mesophilic enzymes are often not well suited for the harsh reaction conditions 
required in industrial processes because of the lack of enzyme stability (Demirjian et al. 2001). Thermostable amylase enzymes that deliver stable performance at high temperatures hold real potential for pharmaceuticals and agrochemicals, and the search for novel thermostable amylase enzymes continues to stimulate the search for microorganisms in extreme environments (Lamilla et al. 2017).

The discovery of a thermostable enzyme produced by Actinobacteria has attracted the interest of researchers and prompted them to explore geothermal regions (e.g. volcanic areas, hydrothermal areas, and geysers) (Mehta and Satyanarayana 2013). Cisolok is one of the geothermal areas in West Java, Indonesia (Purnomo and Pichler 2014), that is still less exploited, and is thus a high-potential area for isolation of novel thermophilic Actinobacteria. In our previous study, we identified a new genus and species of Actinobacteria from soil in the geothermal area of Cisolok, namely Gandjariella thermophila gen. nov., sp. nov., which has the ability to hydrolyze $1 \%(\mathrm{w} / \mathrm{v})$ starch at temperature of $45^{\circ} \mathrm{C}$ (Ningsih et al. 2019, pers. comm.). Sjamsuridzal et al. (unpublished data) found two isolates of thermophilic Actinobacteria (designated as LC2-6A and LC2-6B, identified as Actinomadura keratinilytica) in a litter sample from the Cisolok geysers that produced various extracellular enzymes, such as amylase, cellulase, and xylanase at $50^{\circ} \mathrm{C}$. The same isolates also showed antibiotic activity at $50^{\circ} \mathrm{C}$ to Gram-positive bacteria, Kocuria rhizophila NBRC $12078^{\mathrm{T}}$ (Yokota et al. unpublished data).

In the framework of taxonomic study and bioprospecting of culturable rare-thermophilic Actinobacteria in geothermal areas in Indonesia, Sjamsuridzal et al. isolated 17 thermophilic Actinobacteria from the soil of Cisolok geysers in 2017. However, so far no information has been reported about their amylolytic activities at high temperatures and their identity based on $16 \mathrm{~S}$ rRNA gene sequence, phylogenetic analyses, and phenotypic characterization.

Until recently, there have been no reports of thermophilic Actinobacteria from Indonesia producing thermostable amylase. Therefore, thermophilic Actinobacteria isolated from a geothermal area of Cisolok could be an important resource for the discovery of new thermostable $\alpha$-amylase, which could be utilized in various industries. The aims of this study were to screen for amylolytic activity of the 17 thermophilic Actinobacteria isolates from a geothermal area of Cisolok and characterize the isolates with greatest potential.

\section{MATERIALS AND METHODS}

\section{Source of the Actinobacterial isolates}

A total of 17 Actinobacteria isolates were obtained during a study on the diversity of thermophilic Actinobacteria from the soil of Cisolok geysers, a geothermal area in West Java, Indonesia. The isolates were selected from three different sampling locations: (A) soil around big geyser (6 57'221'S, 106²7'507’E); (B) soil around small geyser (6 $\left.6^{\circ} 7^{\prime} 189^{\prime \prime} \mathrm{S}, 106^{\circ} 27^{\prime} 365^{\prime \prime} \mathrm{E}\right)$; (C.1) soil under Gmelina tree (6 $\left.{ }^{\circ} 57^{\prime} 482^{\prime \prime S}, 106^{\circ} 28^{\prime} 655^{\prime} \mathrm{E}\right)$; and (C.2) soil under Bamboo tree (6 $6^{\circ} 57^{\prime} 482$ 'S, 106 $\left.28^{\prime} 655^{\prime \prime} \mathrm{E}\right)$ (Table 1). Sampling locations in the geothermal area of Cisolok are shown in Figure 1. The isolates were grown on International Streptomyces Project (ISP) 1 agar medium and incubated at $45{ }^{\circ} \mathrm{C}$ for seven days. The isolates were preserved as agar block in $20 \%$ (v/v) glycerol at $-80{ }^{\circ} \mathrm{C}$, and as lyophilized cells for long-term preservation (Ningsih et al. 2019, pers. comm.). All isolates were deposited at Universitas Indonesia Culture Collection (UICC), Department of Biology, Faculty of Mathematics and Natural Sciences, Universitas Indonesia, Depok, Indonesia.

\section{Screening for amylolytic activity}

Screening was conducted on Minimal (Mm) agar medium according to Meddeb-Mouelhi et al. (2014) with the addition of $1 \%(\mathrm{w} / \mathrm{v})$ soluble starch and incubated at 45 , 50,55 , and $60^{\circ} \mathrm{C}$ for up to seven days. The Mm agar without the addition of soluble starch served as a control. The degradation of starch was detected by flooding the plates with $1 \%(\mathrm{v} / \mathrm{v})$ Lugol's iodine solution. Clear zones around the colonies indicated positive results for amylase activity (Nithya et al. 2017). Growth ability at various high temperatures was also tested on ISP 1 agar medium at 45, 50,55 , and $60^{\circ} \mathrm{C}$ for up to seven days. The experiment was carried out in triplicate.

\section{Identification of selected isolates by sequencing of the 16S rRNA gene}

DNA extraction for 16S rRNA gene sequencing was conducted from mycelial suspensions of selected isolates grown in ISP1 broth medium at $45^{\circ} \mathrm{C}$ for seven days. DNA was extracted using the genomic DNA mini kit [Geneaid] following the instructions of the kit protocol. PCR amplification for the 16S rRNA gene was carried out using the conditions specified in the MyTaq ${ }^{\mathrm{TM}}$ Red Mix [Bioline] protocol, with universal primers for the 16S rRNA gene: $9 \mathrm{~F}$ $\left(5^{\prime}\right.$-GAGTTTGATCCTGGCTCAG-3'), and 1510R (5'GGCTACCTTGTTACGA-3' ) as described by Weisburg et al. (1991). The PCR conditions specified initial denaturation at $95^{\circ} \mathrm{C}$ for three minutes, 35 cycles of denaturation at $95^{\circ} \mathrm{C}$ for 15 seconds, annealing at $56^{\circ} \mathrm{C}$ for 15 seconds, and extension at $72^{\circ} \mathrm{C}$ for one minute. The amplified 16S rRNA gene were sequenced using the 1st BASE DNA sequencing service (http://www.baseasia.com/dna-sequencing-services), using the following universal eubacterial primers for $16 \mathrm{~S}$ rRNA gene: $785 \mathrm{~F}$ $\left(5^{\prime}\right.$-GGATTAGATACCCTGGTA-3'), 800R (5'TACCAGGGTATCTAATCC-3' $\left.3^{\prime}\right), \quad 27 \mathrm{~F} \quad\left(5^{\prime}-\right.$ AGAGTTTGATCMTGGCTCAG-3'), and 1492R (5'TACGGYTACCTTGTTACGACTT-3') (Weisburg et al. 1991; Jin et al. 2015).

The nearly full-length 16S rRNA gene sequences of selected thermophilic Actinobacteria isolates were analyzed using ChromasPro v.2.1.8 software and through a sequence-similarity search on EzTaxon-e (https://www.ezbiocloud.net/) (Yoon et al. 2017). The sequences of selected isolates were aligned with the sequences of type strains retrieved from the 
DDBJ/EMBL/GenBank databases. Phylogenetic analysis was conducted in the Molecular Evolutionary Genetics Analysis version 7.0.26 (MEGA v7.0.26) software package (Kumar et al. 2016) using the neighbor-joining method (Saitou and Nei 1987) with bootstrap values based on 1000 replications (Felsenstein 1985). Evolutionary distances of the phylogenetic tree were calculated according to the Kimura two-parameter method (Kimura 1980).

\section{Morphological, physiological, and biochemical characterization of selected isolates}

Morphological characteristics of selected isolates were examined on ISP 1 agar medium incubated at $45{ }^{\circ} \mathrm{C}$ for seven to 14 days (Puhl et al. 2009). The characteristic of the colony, the production of soluble pigment, and the color of the substrate hyphae were determined according to Shirling and Gottlieb (1966). Substrate and aerial mycelia were observed on $50 \%$ of Reasoner's 2A (R2A; Reasoner and Geldreich 1985) gellan medium incubated at $45{ }^{\circ} \mathrm{C}$ for seven days. The formation of aerial hyphae and the morphology of the substrate mycelia were observed using a digital microscope (Hirox; KH-8700).

All physiological tests were conducted on ISP 1 and ISP 2 medium incubated at $45{ }^{\circ} \mathrm{C}$ for seven to 14 days (Puhl et al. 2009). Growth at temperatures of 25, 30, 35, $40,45,50,55,60$, and $65{ }^{\circ} \mathrm{C}$; and at various $\mathrm{NaCl}$ concentrations $(1,2,3,4,5,6,7,8$, and $9 \% \mathrm{w} / \mathrm{v})$ were tested on ISP 2 medium. The ability to grow at $\mathrm{pH} 4.0-10.0$ was determined on ISP 1 medium using buffer systems according to $\mathrm{Xu}$ et al. (2005): $\mathrm{pH} 4.0-5.0,0.1 \mathrm{M}$ citric acid/0.1 M sodium citrate; $\mathrm{pH}$ 6.0-8.0, $0.1 \quad \mathrm{KH}_{2} \mathrm{PO}_{4} / 0.1$ $\mathrm{NaOH}$; pH 9.0-10.0, 0.1 M NaHCO $3 / 0.1 \mathrm{M} \mathrm{Na}_{2} \mathrm{CO}_{3}$; $\mathrm{pH}$ 11.0, 0.05 $\mathrm{M} \mathrm{Na}_{2} \mathrm{HPO}_{4} / 0.1 \mathrm{M} \mathrm{NaOH} ; \mathrm{pH} 12.0-13.0,0.2 \mathrm{M}$ $\mathrm{KCl} / 0.2 \mathrm{M} \mathrm{NaOH}$. All physiological tests were performed in triplicate.
The ability of selected isolates to use various carbon sources: $D$-cellobiose, $D$-fructose, $D$-galactose, $D$-glucose, $D$-mannitol, $D$-mannose, $D$-melibiose, $D$-raffinose, $D$-ribose, $D$-xylose, $L$-arabinose, $L$-rhamnose, $L$-sorbose, lactose, maltose, myo-inositol, ribitol, sucrose, trehalose, and xylitol, was examined on ISP 9 agar medium according to Shirling and Gottlieb (1966). Carbon sources were added at $1 \%(\mathrm{w} / \mathrm{v})$ final concentration and the medium was incubated at $45^{\circ} \mathrm{C}$ for seven to 14 days. The degradation of adenine $(0.5 \% \mathrm{w} / \mathrm{v})$, casein $(1 \% \mathrm{w} / \mathrm{v}$ skimmed milk), gelatin $(0.4 \% \mathrm{w} / \mathrm{v})$, guanine $(0.05 \% \mathrm{w} / \mathrm{v})$, hypoxanthine $(0.4 \% \mathrm{w} / \mathrm{v}), \mathrm{L}$-tyrosine $(0.5 \% \mathrm{w} / \mathrm{v})$, and xanthine $(0.4 \%$ $\mathrm{w} / \mathrm{v})$ were detected in modified Bennett's agar (MBA) medium (Williams et al. 1983). Tween 80 (1\% v/v) utilization was examined for opacity on Sierra's (1957) medium. Catalase production was observed by the addition of $3 \%(\mathrm{v} / \mathrm{v})$ hydrogen peroxide to colonies grown on MBA medium, after seven days incubation at $45^{\circ} \mathrm{C}$ (Williams et al. 1983). All biochemical tests were performed in triplicate.

Table 1. The list of Actinobacterial isolates from three sampling locations in geothermal area of Cisolok, Indonesia.

\begin{tabular}{cccc}
\hline No. & $\begin{array}{c}\text { Sampling } \\
\text { location 1 } \\
\text { Big geyser }\end{array}$ & $\begin{array}{c}\text { Sampling } \\
\text { location 2 } \\
\text { Small geyser }\end{array}$ & $\begin{array}{c}\text { Sampling } \\
\text { location 3 } \\
\text { Soil forest near } \\
\text { Cisolok geysers }\end{array}$ \\
\hline 1. & SL1-1-R-2 & SL2-2-R-1 & SL3-1-R-14 \\
2. & SL1-1-R-4 & SL2-2-R-12 & SL3-1-R-16 \\
3. & SL1-1-R-7 & SL2-2-R-15 & SL3-2-R-5 \\
4. & SL1-1-R-8 & & SL3-2-R-17 \\
5. & SL1-2-R-2 & & SL3-2-R-18 \\
6. & SL1-2-R-3 & & SL3-2-R-33 \\
7. & SL1-2-R-4 & & SL3-2-R-37 \\
Total & 7 & 3 & 7 \\
\hline
\end{tabular}

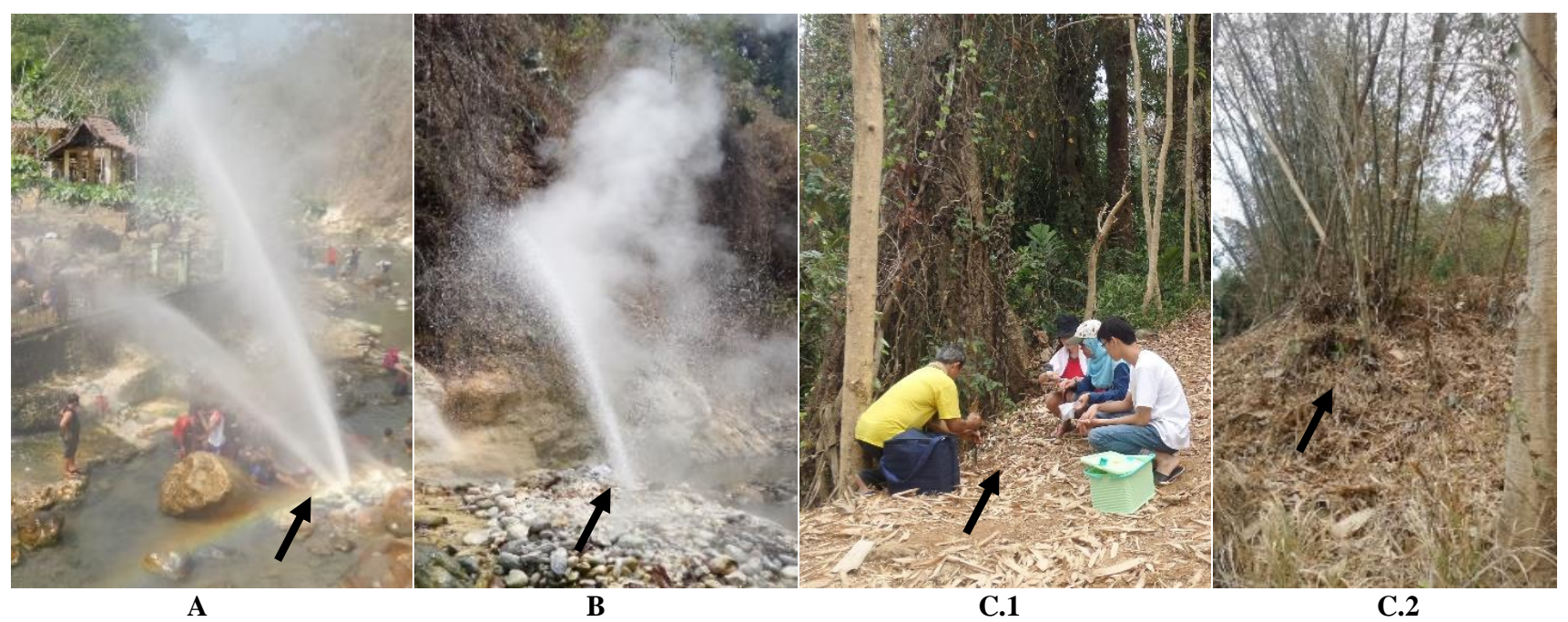

Figure 1. Sampling locations in geothermal area of Cisolok, Indonesia: A. Soil around big geyser; B. Soil around small geyser; C.1. Soil under Gmelina tree, and C.2. Soil under Bamboo tree 


\section{RESULTS AND DISCUSSION}

\section{Amylolytic activity of thermophilic Actinobacteria}

The ability of the 17 isolates of Actinobacteria to grow at various temperatures was tested on ISP 1 agar medium incubated at $45,50,55$, and $60^{\circ} \mathrm{C}$ for three to seven days (Table 2). The results showed that all isolates grew at 45 ${ }^{\circ} \mathrm{C}$. Sixteen isolates were able to grow at $50^{\circ} \mathrm{C}$, and six isolates at $55^{\circ} \mathrm{C}$. The ability to grow at $60^{\circ} \mathrm{C}$ was only shown in five isolates, designated SL1-2-R-2, SL1-2-R-3, SL1-2-R-4, SL2-2-R-15, and SL3-1-R-16. These result confirmed that the 17 isolates of thermophilic Actinobacteria isolated from the soil of Cisolok geysers are thermophiles. According to Shivlata and Satyanarayana (2015), thermophilic Actinobacteria grow well at temperatures ranging from 40 to $80^{\circ} \mathrm{C}$.

The starch degradation ability of the 17 isolates as tested on Mm agar medium supplemented with $1 \%(\mathrm{w} / \mathrm{v})$ soluble starch is shown in Table 3. Amylolytic activity from the isolates was observed using the starch-iodine method based on the qualitative observation of the decrease in the iodine color intensity. In this study, 15, 13, and four out of 17 isolates were positive for amylolytic activity at 45 , 50, and $55^{\circ} \mathrm{C}$, respectively, while only three isolates showed growth and amylolytic activity at $60^{\circ} \mathrm{C}$. Meanwhile, two isolates, designated SL2-2-R-15 and SL3$1-\mathrm{R}-16$, showed negative results for amylolytic activity at 45,50 , and $55^{\circ} \mathrm{C}$, even after seven days of incubation (Table 3). Figure 2 shows the presence of amylolytic activity on three representative isolates, designated SL1-2R-2, SL1-2-R-3, and SL1-2-R-4, at temperatures of 45-60 ${ }^{\circ} \mathrm{C}$, indicated by the formation of clear zones around the colonies. Fifteen isolates showed clear zones on $1 \%$ soluble starch, indicating that they produce $\alpha$-amylase. Polysaccharides, with the addition of iodine $\left(\mathrm{I}_{2}\right)$ will bind and form a dark purple color. Amylose plays a role in the formation of the dark purple color in the reaction with iodine. The clear zone formed indicates that starch has been hydrolyzed by amylase to oligosaccharides or monosaccharides (Immel and Lichtenthaler 2000; Lalitha et al. 2012).

The clear zones formed around the colonies have different diameters at each incubation temperature up to 60 ${ }^{\circ} \mathrm{C}$. The clear zones of the isolates incubated at 45,50 , and $55{ }^{\circ} \mathrm{C}$ were bigger than the clear zones of the isolates incubated at $60^{\circ} \mathrm{C}$ (Figure 2). These results indicated that the higher the incubation temperature, the lower the colonies' ability to produce amylase. According to Haritha et al. (2010), there are many factors which affect Actinobacteria growth and enzyme production e.g. temperature, $\mathrm{pH}$, and substrate including the chemical and biological environment. In the present study, only three isolates grew and showed amylolytic activity at temperatures from 45 to $60^{\circ} \mathrm{C}$ after seven days of incubation. The three selected isolates, selected based on their amylolytic activity at $60^{\circ} \mathrm{C}$, were further identified by molecular analysis based on 16S rRNA gene sequences data.

\section{Phylogenetic analysis of selected isolates}

The 16S rRNA gene sequences of three selected isolates (SL1-2-R-2, SL1-2-R-3, and SL1-2-R-4) were sequenced using four universal eubacterial primers $(27 \mathrm{~F}$, $785 \mathrm{~F}, 800 \mathrm{R}$, and 1492R). The nearly full-length $16 \mathrm{~S}$ rRNA gene sequences of SL1-2-R-2 (1492 bp), SL1-2-R-3 (1497 bp), and SL1-2-R-4 (1456 bp) were obtained. The GenBank/EMBL/DDBJ accession numbers for the $16 \mathrm{~S}$ rRNA gene sequence of three isolates (SL1-2-R-2, SL1-2R-3, and SL1-2-R-4) are LC484202-LC484204.

Table 2. Growth of 17 thermophilic Actinobacteria on ISP 1 agar medium for seven days.

\begin{tabular}{lcccc}
\hline \multirow{2}{*}{$\begin{array}{c}\text { Isolate } \\
\text { code }\end{array}$} & \multicolumn{4}{c}{ Temperatures of incubation $\left({ }^{\circ} \mathbf{C}\right)$} \\
\cline { 2 - 5 } & $\mathbf{4 5}$ & $\mathbf{5 0}$ & $\mathbf{5 5}$ & $\mathbf{6 0}$ \\
\hline SL1-1-R-2 & + & + & - & $\mathrm{n} / \mathrm{a}$ \\
SL1-1-R-4 & + & + & - & $\mathrm{n} / \mathrm{a}$ \\
SL1-1-R-7 & + & + & - & $\mathrm{n} / \mathrm{a}$ \\
SL1-1-R-8 & + & + & - & $\mathrm{n} / \mathrm{a}$ \\
SL1-2-R-2 & + & + & + & + \\
SL1-2-R-3 & + & + & + & + \\
SL1-2-R-4 & + & + & + & + \\
SL2-2-R-1 & + & + & + & - \\
SL2-2-R-12 & + & + & - & $\mathrm{n} / \mathrm{a}$ \\
SL2-2-R-15 & + & + & + & + \\
SL3-1-R-14 & + & + & - & $\mathrm{n} / \mathrm{a}$ \\
SL3-1-R-16 & + & + & + & + \\
SL3-2-R-5 & + & + & - & $\mathrm{n} / \mathrm{a}$ \\
SL3-2-R-17 & + & + & - & $\mathrm{n} / \mathrm{a}$ \\
SL3-2-R-18 & + & - & - & $\mathrm{n} / \mathrm{a}$ \\
SL3-2-R-33 & + & + & - & $\mathrm{n} / \mathrm{a}$ \\
SL3-2-R-37 & + & + & - & $\mathrm{n} / \mathrm{a}$ \\
Total & 17 & 16 & 6 & 5 \\
\hline
\end{tabular}

Note: (+): growth; (-): no growth; (n/a): not available, the test was not conducted

Table 3. Amylolytic activities of 17 thermophilic Actinobacteria on $\mathrm{Mm}$ agar supplemented with $1 \%$ (w/v) starch for seven days.

\begin{tabular}{lcccc}
\hline \multirow{2}{*}{ Isolate codes } & \multicolumn{5}{c}{ Temperatures of incubation $\left({ }^{\circ} \mathbf{C}\right)$} \\
\cline { 2 - 5 } & $\mathbf{4 5}$ & $\mathbf{5 0}$ & $\mathbf{5 5}$ & $\mathbf{6 0}$ \\
\hline SL1-1-R-2 & + & + & $*$ & $\mathrm{n} / \mathrm{a}$ \\
SL1-1-R-4 & + & + & $*$ & $\mathrm{n} / \mathrm{a}$ \\
SL1-1-R-7 & + & + & $*$ & $\mathrm{n} / \mathrm{a}$ \\
SL1-1-R-8 & + & + & $*$ & $\mathrm{n} / \mathrm{a}$ \\
SL1-2-R-2 & + & + & + & + \\
SL1-2-R-3 & + & + & + & + \\
SL1-2-R-4 & + & + & + & + \\
SL2-2-R-1 & + & + & + & $*$ \\
SL2-2-R-12 & + & + & $*$ & $\mathrm{n} / \mathrm{a}$ \\
SL2-2-R-15 & - & - & - & $\mathrm{n} / \mathrm{a}$ \\
SL3-1-R-14 & + & $*$ & $*$ & $\mathrm{n} / \mathrm{a}$ \\
SL3-1-R-16 & - & - & - & $\mathrm{n} / \mathrm{a}$ \\
SL3-2-R-5 & + & + & $*$ & $\mathrm{n} / \mathrm{a}$ \\
SL3-2-R-17 & + & + & $*$ & $\mathrm{n} / \mathrm{a}$ \\
SL3-2-R-18 & + & $*$ & $*$ & $\mathrm{n} / \mathrm{a}$ \\
SL3-2-R-33 & + & + & $*$ & $\mathrm{n} / \mathrm{a}$ \\
SL3-2-R-37 & + & + & $*$ & $\mathrm{n} / \mathrm{a}$ \\
Total & 15 & 13 & 4 & 3 \\
\hline
\end{tabular}

Note: (+): amylase produced; (-): not produced; (*): no growth; $(\mathrm{n} / \mathrm{a})$ : not available, the test was not conducted 
A sequence-similarity search through EzTaxon-e (https://www.ezbiocloud.net/) showed that these three isolates (SL1-2-R-2, SL1-2-R-3, and SL1-2-R-4) have the highest similarities to members of the genus Actinomadura, and are closely related to A. keratinilytica WCC- $2265^{\mathrm{T}}$ (100\%, 99.93\%, and $100 \%$, respectively) and $A$. miaoliensis BC $44 \mathrm{~T}-5^{\mathrm{T}}(98.81 \%, 98.74 \%$, and $98.91 \%$, respectively). The genus Actinomadura is a member of family Thermomonosporaceae of phylum Actinobacteria (Trujillo and Goodfellow 2015). The phylogenetic tree of the three isolates is shown in Figure 3. Based on a phylogenetic comparison, these three isolates were considered as members of the genus Actinomadura, and were determined to be closely related to A. keratinilytica, A. miaoliensis, A. rubrobrunea, and A. viridilutea, with strong bootstrap supports (94\%). All of three isolates were grouped together in a monophyletic group with the type strain of A. keratinilytica WCC- $2265^{\mathrm{T}}$ as their most closely related species, with $100 \%$ bootstrap support. Based on the percentage of sequence similarity and the phylogenetic placement, all three isolates were identified as $A$. keratinilytica.

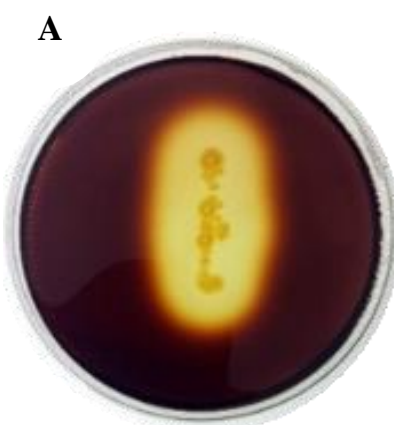

$45^{\circ} \mathrm{C}$

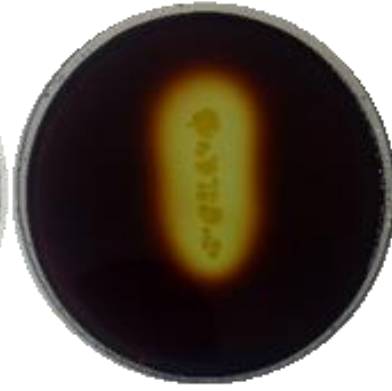

$50{ }^{\circ} \mathrm{C}$

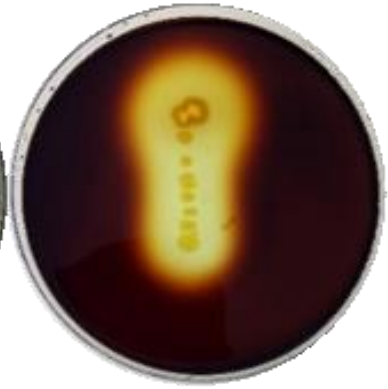

$55^{\circ} \mathrm{C}$

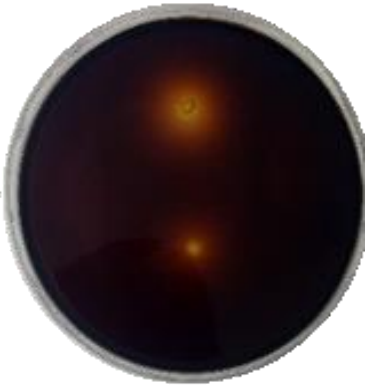

$60^{\circ} \mathrm{C}$

B

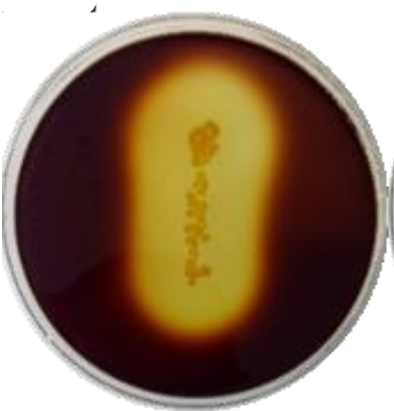

$45^{\circ} \mathrm{C}$

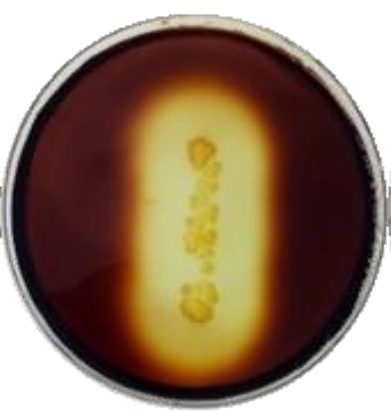

$50{ }^{\circ} \mathrm{C}$

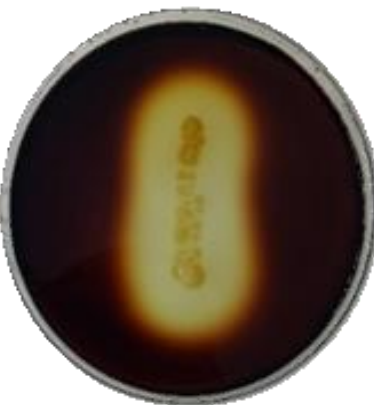

$55^{\circ} \mathrm{C}$

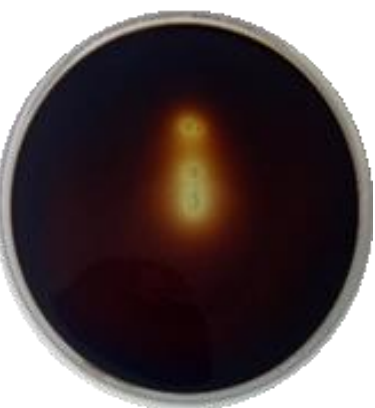

$60^{\circ} \mathrm{C}$

C

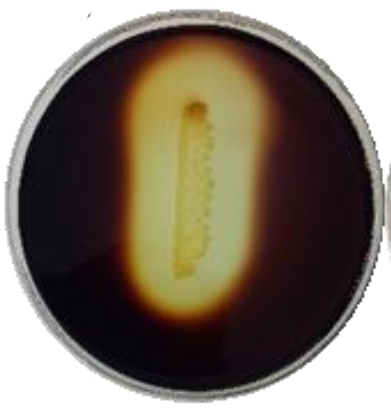

$45^{\circ} \mathrm{C}$

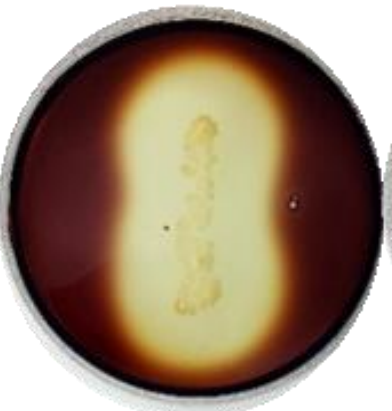

$50{ }^{\circ} \mathrm{C}$

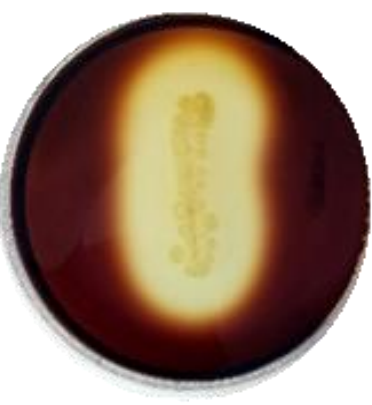

$55^{\circ} \mathrm{C}$

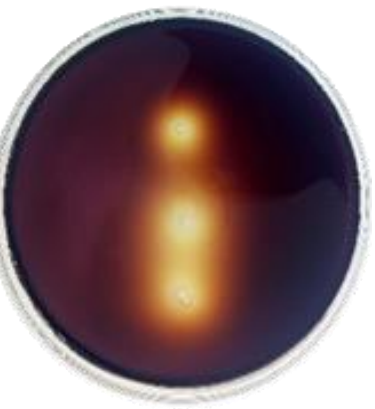

$60^{\circ} \mathrm{C}$

Figure 2. Amylolytic activity of thermophilic Actinobacteria isolates on Mm agar medium supplemented with $1 \%$ (w/v) starch, incubated at 45 to $60{ }^{\circ} \mathrm{C}$ for three to seven days; A. SL1-2-R-2, B. SL1-2-R-3, C. SL1-2-R-4. The clear zone formed indicates that starch has been hydrolyzed 


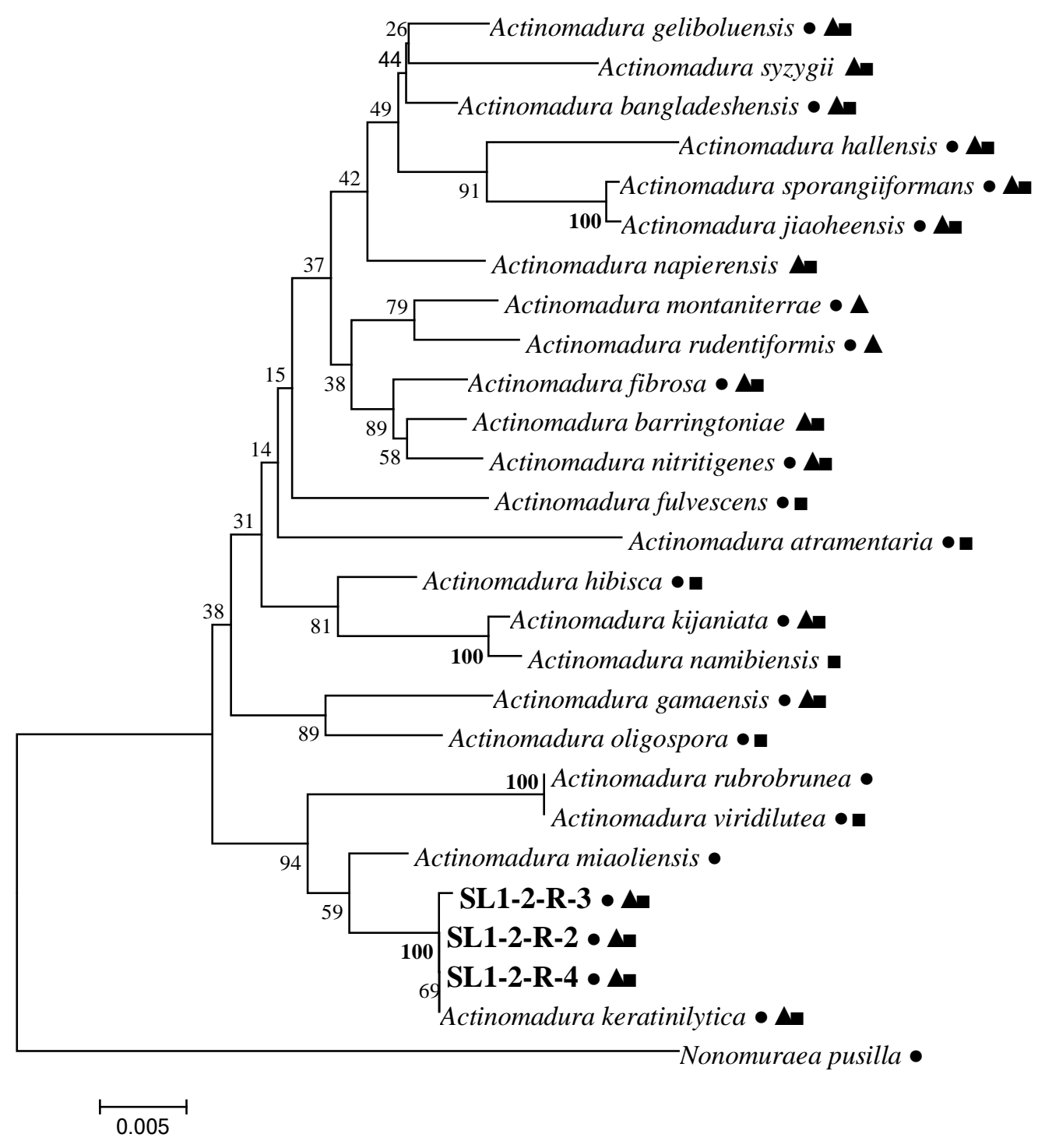

Figure 3. Phylogenetic relationships between three isolates (SL1-2-R-2; SL1-2-R-3; SL1-2-R-4) and type strains of related species of the genus Actinomadura based on nearly full-length 16S rRNA gene sequences. The phylogenetic tree was reconstructed by the neighbor-joining tree (Saitou and Nei 1987) using the MEGA software package (Kumar et al. 2016). Nonomuraea pusilla IFO 14684 was used as an outgroup. Numbers at branch points indicate bootstrap percentages based on 1000 replications (Felsenstein 1985); Bar 0.005 , represents substitutions per nucleotide position. $\bullet$ : thermophilic, temperature range from 40 to $80^{\circ} \mathrm{C}$ (Shivlata and Satyanarayana 2015); $\boldsymbol{\Delta}$ : produces amylase; $\mathbf{m}$ : produces other enzymes

The phylogenetic tree in Figure 3 shows that the three isolates (SL1-2-R-2, SL1-2-R-3, and SL1-2-R-4) and the type strain of $A$. keratinilytica $\mathrm{WCC}-2265^{\mathrm{T}}$ were grouped together with thermophilic species of Actinomadura, e.g. A. rubrobrunea, A. viridilutea, and A. miaoliensis. According to Trujillo and Goodfellow (2012), A. rubrobrunea and A. viridilutea are thermophilic, with growth range between 37 and $65{ }^{\circ} \mathrm{C}$. Tseng et al. (2009) reported that A. miaoliensis has a growth range between 25 and $55{ }^{\circ} \mathrm{C}$, and $A$. keratinilytica has growth range between 30 and $60{ }^{\circ} \mathrm{C}$ (Sukkhum et al. 2011) with optimal growth is at $45^{\circ} \mathrm{C}$ (Puhl et al. 2009). As shown in Figure 3, the three isolates and all closely related species are thermophilic, except for three species: A. barringtoniae, A. syzygii, and $A$. napierensis. These three species have growth temperature lower than $40^{\circ} \mathrm{C}$ (Cook et al. 2005; Rachniyom et al. 2015; Rachniyom et al. 2018) (Table 4).

As seen in Table 4, most closely related species of the three isolates in the genus Actinomadura are thermophilic and are able to produce amylase, other enzymes, or both. The type strain of A. keratinilytica $\mathrm{WCC}-2265^{\mathrm{T}}$ displayed the ability to degrade keratin and utilize it as a sole carbon and nitrogen source (Puhl et al. 2009). Sukkhum et al. (2011) reported that A. keratinilytica strain T16-1, which was isolated from a soil sample, produces several enzymes, e.g. amylase, cellulose, gelatinase, and protease. 
Table 4. List of three selected isolates and the type strains from the genus Actinomadura used in the phylogenetic analyses and their salient characteristics

\begin{tabular}{|c|c|c|c|c|c|c|c|}
\hline Species & $\begin{array}{c}\text { Strain } \\
\text { no. }\end{array}$ & $\begin{array}{c}\text { Accession } \\
\text { no. }\end{array}$ & $\begin{array}{c}\text { Growth } \\
\text { range }\left({ }^{\circ} \mathrm{C}\right)\end{array}$ & Amylase & $\begin{array}{c}\text { Other } \\
\text { enzymes }\end{array}$ & Sources & Reference \\
\hline A. keratinilytica & SL1-2-R-2 & LC484202 & $25-60$ & + & + & Soil & This study \\
\hline A. keratinilytica & SL1-2-R-3 & LC484203 & $25-60$ & + & + & Soil & This study \\
\hline A. keratinilytica & SL1-2-R-4 & LC484204 & $25-60$ & + & + & Soil & This study \\
\hline A. keratinilytica & WCC-2265 & EU637009 & $30-60$ & + & + & Compost & $\begin{array}{l}\text { Puhl et al. (2009) } \\
\text { Sukkhum et al. (2011) }\end{array}$ \\
\hline A. miaoliensis & BC 44T-5 & EF116925 & $25-55$ & - & nd & Soil & $\begin{array}{l}\text { Tseng et al. (2009) } \\
\text { Hoang et al. (2013) }\end{array}$ \\
\hline A. rubrobrunea & NBRC 15275 & BCQU01000204 & $37-65$ & nd & nd & Soil & Trujillo and Goodfellow (2012) \\
\hline A. viridilutea & NBRC 14480 & D86943 & $37-65$ & nd & + & Desert soil & Trujillo and Goodfellow (2012) \\
\hline A. hibisca & NBRC 15177 & BCRO01000158 & $15-40$ & nd & + & Soil & Tomita et al. (1990) \\
\hline A. gamaensis & NEAU-Gz5 & KT989505 & $15-40$ & + & + & Soil & Abagana et al. (2016) \\
\hline A. montaniterrae & CYP1-1B & LC126428 & $20-45$ & + & nd & Soil & Songsumanus et al. (2016) \\
\hline A. barringtoniae & GKU 128 & KF667497 & $14-38$ & + & + & Roots & Rachniyom et al. (2018) \\
\hline A. oligospora & ATCC 43269 & AF163118 & $15-42$ & - & + & Soil & Mertz and Yao (1986) \\
\hline A. nitritigenes & DSM 44137 & AY035999 & 45 & + & + & $\begin{array}{l}\text { Experimental } \\
\text { biofilters }\end{array}$ & Trujillo and Goodfellow (2012) \\
\hline A. fibrosa & ATCC 49459 & AF163114 & $20-45$ & + & + & Soil & Trujillo and Goodfellow (2012) \\
\hline A. kijaniata & NBRC 14229 & BCQR01000335 & $28-50$ & + & + & Soil & Horan and Brodsky (1982) \\
\hline A. namibiensis & DSM 44197 & AJ420134 & 28 & nd & + & Soil & Wink et al. (2003) \\
\hline A. geliboluensis & A8036 & HQ157187 & $20-45$ & + & + & Soil & Sazak et al. (2012) \\
\hline A. syzygii & GKU 157 & KF667496 & $20-34$ & + & + & Roots & Rachniyom et al. (2015) \\
\hline A. fulvescens & IFO 14347 & U49005 & $10-45$ & nd & + & nd & $\begin{array}{l}\text { Terekhova et al. (1982) } \\
\text { Wink et al. (2003) }\end{array}$ \\
\hline A. hallensis & H647-1 & DQ076484 & $20-45$ & + & + & Soil & Lee and Jeong (2006) \\
\hline A. bangladeshensis & $3-46-b 3$ & $\mathrm{AB} 331652$ & $20-45$ & + & + & Soil & Lee (2012) \\
\hline A. jiaoheensis & NEAU-Jh1-3 & KM000835 & $15-42$ & + & + & Soil & Zhao et al. (2015) \\
\hline $\begin{array}{l}\text { A. } \\
\text { sporangiiformans }\end{array}$ & NEAU-Jh2-5 & KM000834 & $20-42$ & + & + & Soil & Zhao et al. (2015) \\
\hline A. rudentiformis & HMC1 & DQ285420 & $30-45$ & + & nd & Soil & Trujillo and Goodfellow (2012) \\
\hline A. atramentaria & IFO 14695 & U49000 & $15-42$ & - & + & Soil & $\begin{array}{l}\text { Miyadoh et al. (1987) } \\
\text { Qin et al. (2009) }\end{array}$ \\
\hline A. napierensis & B60 & AY568292 & 28 & + & + & Soil & Cook et al. (2005) \\
\hline
\end{tabular}

Note: +: thermophilic, able to produce amylase/other enzymes; -: mesophilic, not able to produce amylase/other enzymes; nd: no data

\section{Morphological, physiological, and biochemical characterization of selected isolates}

The characteristics of the three selected isolates (SL1-2R-2, SL1-2-R-3, and SL1-2-R-4) as the genus Actinomadura were also confirmed by conducting morphological, physiological, and biochemical analyses. The characteristics comparison between all three isolates with closely related species from the genus Actinomadura is shown in Table 5. All three isolates are aerobic, Gramstained positive, and catalase positive. They grow at temperature of 25 to $60^{\circ} \mathrm{C}$ (optimum, 45 to $50^{\circ} \mathrm{C}$ ), at $\mathrm{pH}$ 6.0-9.0 (optimum, $\mathrm{pH} 7.0-8.0$ ), and concentrations of $0-5 \%$ (optimum, $1 \%$ ) NaCl in the medium (Table 5). This data is well supported by Puhl et al. (2009) and Sukkhum et al. (2011). According to Puhl et al. (2009), the type strain of A. keratinilytica $\mathrm{WCC}-2265^{\mathrm{T}}$ has a temperature growth range between 30 and $55^{\circ} \mathrm{C}$, with optimal growth at $45^{\circ} \mathrm{C}$. Meanwhile, Sukkhum et al. (2011) reported that the growth range of A. keratinilytica strain T16-1 isolated from a soil sample was 30 to $60^{\circ} \mathrm{C}$.
The isolates showed optimum growth on ISP 1, ISP 2, ISP 3, and modified Bennett's media, solidified with $2 \%$ agar or gellan. The colonies were ivory, with wrinkled surfaces on ISP 2 medium, incubated at $45^{\circ} \mathrm{C}$ for seven days (Figure 4). Substrate and aerial mycelia of all isolates, observed on $50 \%$ of R2A gellan medium, are nonfragmented, branched, with ivory color, and showed flexuous spore arrangement (data not shown). These morphological characteristics are consistent with the description of species A. keratinilytica (Puhl et al. 2009).

The SL1-2-R-2 isolate was able to utilize 18 out of 20 sole carbon sources tested, all except for $D$-galactose and $D$ mannitol. The SL1-2-R-3 and SL1-2-R-4 isolates were not able to utilize $D$-fructose, $D$-galactose, and $D$-mannitol. The type strain of A. keratinilytica, WCC-2265 ${ }^{\mathrm{T}}$ (Puhl et al. 2009), was able to utilize $D$-fructose and $D$-mannitol as sole carbon sources. Degradative tests showed that all isolates hydrolyzed all tested compounds, excluding adenine for isolates SL1-2-R-3 and SL1-2-R-4, while currently, no data is available for A. keratinilytica $\mathrm{WCC}-2265^{\mathrm{T}}$ (Table 5). 


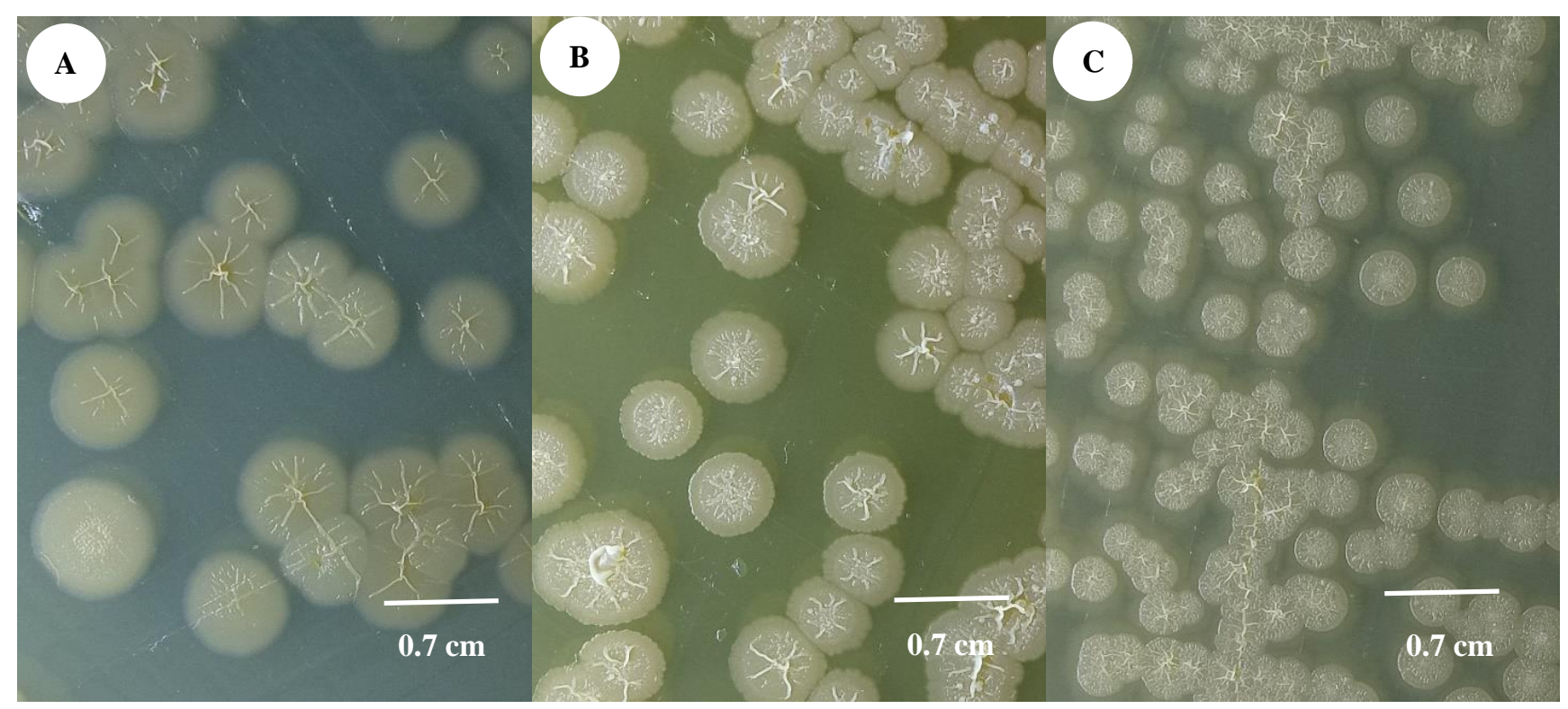

Figure 4. Colony morphology of three selected thermophilic Actinobacteria isolates on ISP 2 agar incubated at $45^{\circ} \mathrm{C}$ for seven days: A. Isolate SL1-2-R-2; B. Isolate SL1-2-R-3; C. Isolate SL1-2-R-4

Table 5. Morphological, physiological, and biochemical characteristics of isolates SL1-2-R-2, SL1-2-R-3, SL1-2-R-4, and the most closely related species from the genus Actinomadura. Strains: 1, SL1-2-R-2 (this study); 2, SL1-2-R-3 (this study); 3, SL1-2-R-4 (this study); 4, A. keratinilytica WCC-2265 ${ }^{\mathrm{T}}$ (Puhl et al. 2009); 5, A. miaoliensis BC 44T- $5^{\mathrm{T}}$ (Horan and Brodsky 1982); 6, A. rubrobrunea NBRC $15275^{\mathrm{T}}$ (Tseng et al. 2009)

\begin{tabular}{|c|c|c|c|c|c|c|}
\hline Characteristics & 1 & 2 & 3 & 4 & 5 & 6 \\
\hline \multicolumn{7}{|l|}{ Spore morphology } \\
\hline Arrangement & Flexuous & Flexuous & Flexuous & $\begin{array}{l}\text { Flexuous- } \\
\text { straight }\end{array}$ & nd & Curved \\
\hline \multicolumn{7}{|l|}{$\begin{array}{l}\text { Colony charac- } \\
\text { teristics on ISP } 2\end{array}$} \\
\hline $\begin{array}{l}\text { Substrate } \\
\text { hyphae }\end{array}$ & Ivory & Ivory & Ivory & nd & nd & nd \\
\hline Aerial hyphae & nd & nd & nd & nd & & \\
\hline Soluble pigment & - & - & - & Brown & nd & nd \\
\hline \multicolumn{7}{|l|}{ Growth at/in } \\
\hline $25^{\circ} \mathrm{C}$ & + & + & + & + & + & - \\
\hline $60^{\circ} \mathrm{C}$ & + & + & + & - & - & + \\
\hline pH 6.0-9.0 & + & + & + & + & nd & nd \\
\hline $0-5 \% \mathrm{NaCl}$ & + & + & + & + & nd & + \\
\hline Catalase activity & + & + & + & nd & nd & nd \\
\hline \multicolumn{7}{|l|}{$\begin{array}{l}\text { Growth on sole } \\
\text { carbon source: }\end{array}$} \\
\hline$D$-Cellobiose & + & + & + & nd & nd & nd \\
\hline$D$-Fructose & + & - & - & + & + & $+1-$ \\
\hline$D$-Galactose & - & - & - & nd & - & nd \\
\hline$D$-Glucose & + & + & + & + & + & + \\
\hline$D$-Mannitol & - & - & - & + & nd & + \\
\hline$D$-Mannose & + & + & + & nd & nd & nd \\
\hline$D$-Melibiose & + & + & + & nd & nd & nd \\
\hline$D$-Raffinose & + & + & + & + & nd & $+/-$ \\
\hline$D$-Ribose & + & + & + & nd & nd & nd \\
\hline$D$-Xylose & + & + & + & + & + & $+/-$ \\
\hline$L$-Arabinose & + & + & + & $+/-$ & - & - \\
\hline$L$-Rhamnose & + & + & + & + & nd & + \\
\hline
\end{tabular}

\begin{tabular}{|c|c|c|c|c|c|c|}
\hline$L$-Sorbose & + & + & + & nd & nd & nd \\
\hline myo-Inositol & + & + & + & + & - & $+/-$ \\
\hline Lactose & + & + & + & nd & nd & nd \\
\hline Maltose & + & + & + & nd & nd & nd \\
\hline Xylitol & + & + & + & nd & nd & nd \\
\hline Ribitol & + & + & + & nd & nd & nd \\
\hline Sucrose & + & + & + & + & nd & + \\
\hline Trehalose & + & + & + & nd & + & nd \\
\hline \multicolumn{7}{|l|}{ Hydrolysis of: } \\
\hline Adenine & + & - & - & nd & nd & nd \\
\hline Casein & + & + & + & nd & + & nd \\
\hline Guanine & + & + & + & nd & nd & nd \\
\hline Hypoxanthine & + & + & + & nd & nd & nd \\
\hline$L$-Tyrosine & + & + & + & nd & + & nd \\
\hline Starch & + & + & + & nd & nd & nd \\
\hline Tween 80 & + & + & + & nd & nd & nd \\
\hline Xanthine & + & + & + & nd & nd & nd \\
\hline
\end{tabular}

Note: (+): positive; (-): negative; (nd): no data

As shown in Table 4, many species of Actinomadura have been isolated from soil, including the three isolates used in this study and all the other isolates named except for A. barringtoniae and A. syzygii (roots); A. keratinilytica (compost); and $A$. nitrigenes (experimental biofilters). According to Trujillo and Goodfellow (2015), the genus Actinomadura is widely distributed in soil and probably has a role in organic matter turnover. Therefore, it can be suggested that soil is promising habitat to explore the diversity of Actinomadura. Actinomadurae are slower growing than streptomycetes (Trujillo and Goodfellow (2015), and are therefore considered rare Actinobacteria, which are often very difficult to isolate and cultivate. This study is the first report for Actinomadura found in the soil of geysers in Indonesia.

In summary, the findings presented in this study show that soil around the geysers of Cisolok supports a 
thermophilic community of Actinobacteria, and almost all isolates are positive for amylolytic activities (at temperatures of 45 to $60^{\circ} \mathrm{C}$ ). Fifteen out of 17 isolates tested showed clear zones on $1 \%$ soluble starch, indicating that they produced $\alpha$-amylase. It can, therefore, be concluded that Actinobacteria in the soil of the Cisolok geysers are a promising source of amylase producers. Based on percentage of sequence similarity, the phylogenetic placement, and phenotypic characterization, the three selected isolates (SL1-2-R-2; SL1-2-R-3; SL1-2R-4) were identified as A. keratinilytica. Further study about their amylase activity and its potential as a thermostable enzyme is needed for further applications.

\section{ACKNOWLEDGEMENTS}

This research was funded by Hibah Publikasi Internasional Terindeks untuk Tugas Akhir Mahasiswa (PITTA) UI 2018 no. 2331/UN2.R3.1/HKP.05.00/2018 to W.S. We would like to acknowledge the financial assistance provided by the Department of Microbial Resources, Graduate School of Agricultural Science, Faculty of Agriculture, Tohoku University, Japan.

\section{REFERENCES}

Abagana AY, Sun P, Liu C, Cao T, Zheng W, Zhao S, Xiang W, Wang X. 2016. A. gamaensis sp. nov., a novel actinomycete isolated from soil in Gama, Chad. Antonie van Leeuwenhoek 109 (6): 833-839.

Barka EA, Vatsa P, Sanchez L, Gaveau-Vaillant N, Jacquard C, Klenk HP, Clement C, Ouhdouch Y, van Wezel GP. 2016. Taxonomy, physiology, and natural products of Actinobacteria. Microbiol Mol Biol Rev 80 (1): 1-43.

Cook AE, le Roes M, Meyers PR. 2005. A. napierensis sp. nov., isolated from soil in South Africa. Intl J Syst Evol Microbiol 55 (2): 703-706.

Demirjian DC, Moris-Varas F, Cassidy CS. 2001. Enzymes from extremophiles. Curr Opin Chem Biol 5 (2): 144-151.

Felsenstein J. 1985. Confidence limits on phylogenies: an approach using the bootstrap. Evolution 39 (4): 783-791.

Gopinath SC, Anbu P, Arshad MK, Lakshmipriya T, Voon CH, Hashim U, Chinni SV. 2017. Biotechnological processes in microbial amylase production. BioMed Res Intl. DOI: 10.1155/2017/1272193.

Haritha R, Siva KK, Jagan MYSYV, Ramana T. 2010. Amylolytic and proteolytic Actinobacteria isolated from marine sediments of Bay of Bengal. Intl J Microbiol Res 1 (2): 37-44.

Hoang KC, Yang SF, Tseng M,Yuan GF. 2013. U.S. Patent No. $8,476,056$. U.S. Patent and Trademark Office, Washington, DC.

Horan AC, Brodsky BC. 1982. A Novel Antibiotic-Producing Actinomadura, A. kijaniata sp. nov. Intl J Syst Evol Microbiol 32 (2): 195-200.

Immel S, Lichtenthaler FW. 2000. The hydrophobic topographies of amylose and its blue iodine complex. Starch-Starke 52 (1): 1-8.

Jin L, Lee HG, Ko SR, Ahn CY, Oh HM. 2015. Jatrophihabitans fulvus sp. nov., an actinobacterium isolated from grass soil. Intl J Syst Evol Microbiol 65 (10): 3476-3480

Kikani BA, Shukla RJ, Singh SP. 2010. Biocatalytic potential of thermophilic bacteria and actinomycetes. Curr Res Technol Educa Topics Appl Microb Microb Biotechnol 2: 1000-1007.

Kimura, M. 1980. A simple method for estimating evolutionary rates of base substitutions through comparative studies of nucleotide sequences. Intl J Mol Evol 16 (2): 111-120.

Kumar S, Stecher G, Tamura T. 2016. MEGA7: Molecular Evolutionary Genetics Analysis version 7 for bigger datasets. Mol Biol Evol 33 (7): 1870-1874

Lalitha P, Shravya K, Arunalakshmi K. 2012. Effect of supplementary carbon and nitrogen sources on amylase production by Trichoderma viride in solid state fermentation. Intl J Life Sciences Biotechnol and Pharma Res 1 (1): 160-163.

Lamilla C, Pavez M, Santos A, Hermosilla A, Llanquinao V, Barrientos L. 2017. Bioprospecting for extracellular enzymes from culturable Actinobacteria from the South Shetland Islands, Antarctica. Polar Biol 40 (3): 719-726.

Lee SD, Jeong HS. 2006. A. hallensis sp. nov., a novel actinomycete isolated from Mt. Halla in Korea. Intl J Systematic and Evolutionary Microbiol 56 (1): 259-264.

Lee SD. 2012. A. meridiana sp. nov., isolated from mountain soil. Intl J Systematic and Evolutionary Microbiol 62 (1): 217-222.

Liu L, Salam N, Jiao JY, Jiang HC, Zhou EM, Yin YR, Ming H, Li WJ. 2016. Diversity of culturable thermophilic Actinobacteria in hot springs in Tengchong, China and studies of their biosynthetic gene profiles. Microbial Ecol 72 (1): 150-162.

Meddeb-Mouelhi F, Moisan JK, Beauregard M. 2014. A comparison of plate assay methods for detecting extracellular cellulase and xylanase activity. Enzyme and Microbial Technol 66: 16-19.

Mehta D, Satyanarayana T. 2013. Diversity of hot environments and thermophilic microbes. In Thermophilic Microbes in Environmental and Industrial Biotechnol: 3-60.

Mertz FP, Yao RC. 1986. A. oligospora sp. nov., the producer of a new polyether antibiotic. Intl J Systematic and Evolutionary Microbiol 36 (2): 179-182.

Miyadoh S, Amano S, Tohyama H, Shomura T. 1987. A. atramentaria, a new species of the Actinomycetales. Intl J Syst Evol Microbiol 37 (4): 342-346.

Nithya K, Muthukumar C, Kadaikunnan S, Alharbi NS, Khaled JM, Dhanasekaran D. 2017. Purification, characterization, and statistical optimization of a thermostable $\alpha$-amylase from desert Actinobacterium Streptomyces fragilis DA7-7. Biotech 7 (5): 350.

Puhl AA, Selinger LB, McAllister TA, Inglis GD. 2009. A. keratinilytica sp. nov., a keratin-degrading actinobacterium isolated from bovine manure compost. Intl J Syst Evol Microbiol 59 (4): 828-834.

Purnomo BJ, Pichler T. 2014. Geothermal systems on the island of Java, Indonesia. Intl J Volcan Geotherm Res 285: 47-59.

Qin S, Zhao GZ, Li J, Zhu WY, Xu LH, Li WJ. 2009. A. flavalba sp. nov., an endophytic actinomycete isolated from leaves of Maytenus austroyunnanensis. Intl J Systematic and Evolutionary Microbiol 59 (10): 2453-2457.

Rachniyom H, Matsumoto A, Indananda C, Duangmal K, Takahashi Y, Thamchaipenet A. 2015. A. syzygii sp. nov., an endophytic actinomycete isolated from the roots of a jambolan plum tree (Syzygium cumini L. Skeels). Intl J Syst Evol Microbiol 65 (6): 19461949.

Rachniyom H, Matsumoto A, Inahashi Y, Take A, Takahashi Y, Thamchaipenet A. 2018. A. barringtoniae sp. nov., an endophytic actinomycete isolated from the roots of Barringtonia acutangula (L.) Gaertn. Intl J Syst Evol Microbiol 68 (5): 1584-1590.

Reasoner DJ, Geldreich EE. 1985. A new medium for the enumeration and subculture of bacteria from potable water. Appl Environ Microbiol 49 (1): 1-7.

Saitou N, Nei M. 1987. The neighbor-joining method: a new method for reconstructing phylogenetic trees. Mol Biol Evol 4 (4): 406-425.

Salwan R, Sharma V. 2018. The role of actinobacteria in the production of industrial enzymes. In: Singh BP, Gupta VK, Passari AK (ed). New and Future Developments in Microbial Biotechnology and Bioengineering. Elsevier, Cambridge, MA.

Sazak A, Camas M, Sproer C, Klenk HP, Sahin N. 2012. A. geliboluensis sp. nov., isolated from soil. Intl J Syst Evol Microbiol 62 (8): 20112017

Shirling ET, Gottlieb D. 1966. Methods for characterization of Streptomyces species. Intl J Syst Bacteriol 16 (3): 313-340.

Shivlata L, Satyanarayana T. 2015. Thermophilic and alkaliphilic Actinobacteria: biology and potential applications. Front Microbiol 6: 1014

Songsumanus A, Kudo T, Ohkuma M, Phongsopitanun W, Tanasupawat S. 2016. A. montaniterrae sp. nov., isolated from mountain soil. Intl J Syst Evol Microbiol 66 (9): 3310-3316.

Sukkhum S, Tokuyama S, Kongsaeree, Tamura T, Ishida Y, Kitpreechavanich V. 2011. A novel poly (L-lactide) degrading thermophilic actinomycetes, A. keratinilytica strain T16-1 and pla sequencing. African Intl J Microbiol Res 5 (18): 2575-2582.

Sundarram A, Murthy TPK. 2014. Alpha-amylase production and applications: a review. Intl J Appl Environ Microbiol 2 (4): 166-175. 
Terekhova LP, Galatenko OA, Preobrazhenskaia TP. 1982. New species, A. fulvescens sp. nov. and A. turkmeniaca sp. nov. and their antagonistic properties. Antibiotiki 27 (2): 87-92.

Trujillo ME and Goodfellow M. 2012. Genus III. Actinomadura Lechevalier and Lechevalier 1970a, 400 AL emend. Kroppenstedt, Stackebrandt, and Goodfellow 1990, 156. In: Bergey's Manual of Systematic Bacteriology. 2nd ed, Vol. 5: Actinobacteria, part B. Springer, New York.

Trujillo ME, Goodfellow M. 2015. Actinomadura. Bergey's Manual of Systematics of Archaea and Bacteria. John Wiley \& Sons, Inc., New York.

Tseng M, Yang SF, Hoang KC, Liao HC, Yuan GF, Liao CC. 2009. A miaoliensis sp. nov., a thermotolerant polyester-degrading actinomycete. Intl J Syst Evol Microbiol 59 (3): 517-520.

Tomita K, Nishio M, Saitoh K, Yamamoto H, Hoshino Y, Ohkuma H, Konishi M, Miyaki T, Oki T. 1990. Pradimicins A, B and C: New antifungal antibiotics. Intl J Antibiot 43 (7): 755-762.

Wang S, Copeland L. 2013. Molecular disassembly of starch granules during gelatinization and its effect on starch digestibility: a review. Food Funct 4 (11): 1564-1580.

Weisburg WG, Barns SM, Pelletier DA, Lane DJ. 1991. 16S ribosomal DNA amplification for phylogenetic study. Intl J Bacteriol: 173 (2): 697-703.
Williams ST, Goodfellow G, Alderson G, Wellington EMH, Sneath PHA, Sackin MJ. 1983. Numerical classification of Streptomyces and related genera. Microbiolology 129 (6): 1743-1813.

Wink J, Kroppenstedt RM, Seibert G, Stackebrandt E. 2003. A. namibiensis sp. nov. Intl J Syst Evol Microbiol 53 (3): 721-724.

Xu P, Li WJ, Tang SK, Zhang YQ, Chen GZ, Chen HH, Xu LH, Jiang CL. 2005. Naxibacter alkalitolerans gen. nov., sp. nov., a novel member of the family 'Oxalobacteraceae' isolated from China. Intl J Syst Evol Microbiol 55 (3): 1149-1153.

Yoon J, Miwa H, Ahmed I, Yokota I, Fujiwara T. 2010. Rhodococcus baikonurensis BTM4c, a boron-tolerant Actinobacterial strain isolated from soil. Biosci Biotechnol Biochem 74 (1): 178-181.

Yoon SH, Ha SM, Kwon S, Lim J, Kim Y, Seo H, Chun J. 2017. Introducing EzBioCloud: a taxonomically united database of $16 \mathrm{~S}$ rRNA gene sequences and whole-genome assemblies. Intl J Syst Evol Microbiol 67 (5): 1613.

Zhao J, Guo L, Sun P, Han C, Bai L, Liu C, Li Y, Xiang W, Wang X. 2015. A. jiaoheensis sp. nov. and A. sporangiiformans sp. nov., two novel actinomycetes isolated from muddy soil and emended description of the genus Actinomadura. Antonie van Leeuwenhoek 108 (6): 1331-1339. 